This article was downloaded by: [Franchino, Fabio][University of Milan]

On: 23 August 2010

Access details: Access Details: [subscription number 919382374]

Publisher Routledge

Informa Ltd Registered in England and Wales Registered Number: 1072954 Registered office: Mortimer House, 3741 Mortimer Street, London W1T 3JH, UK

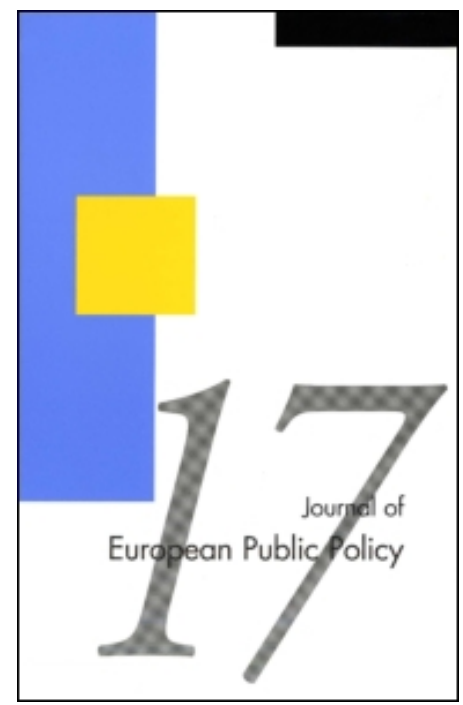

Journal of European Public Policy

Publication details, including instructions for authors and subscription information:

http://www.informaworld.com/smpp/title content=t713685697

\title{
The role of subnational authorities in the implementation of EU directives
}

Enrico Borghetto; Fabio Franchino

Online publication date: 04 August 2010

To cite this Article Borghetto, Enrico and Franchino, Fabio(2010) 'The role of subnational authorities in the implementation of EU directives', Journal of European Public Policy, 17: 6, $759-780$

To link to this Article: DOI: 10.1080/13501763.2010.486972

URL: http://dx.doi.org/10.1080/13501763.2010.486972

\section{PLEASE SCROLL DOWN FOR ARTICLE}

Full terms and conditions of use: http://www.informaworld.com/terms-and-conditions-of-access.pdf

This article may be used for research, teaching and private study purposes. Any substantial or systematic reproduction, re-distribution, re-selling, loan or sub-licensing, systematic supply or distribution in any form to anyone is expressly forbidden.

The publisher does not give any warranty express or implied or make any representation that the contents will be complete or accurate or up to date. The accuracy of any instructions, formulae and drug doses should be independently verified with primary sources. The publisher shall not be liable for any loss, actions, claims, proceedings, demand or costs or damages whatsoever or howsoever caused arising directly or indirectly in connection with or arising out of the use of this material. 


\title{
The role of subnational authorities in the implementation of EU directives
}

\author{
Enrico Borghetto and Fabio Franchino
}

\begin{abstract}
Studies on the role of regions in the EU policy process concentrate mainly on policy formulation and implementation of regional funds. In this article, we redress this bias by investigating the formal role of subnational authorities in the implementation of EU regulatory policies, specifically in the transposition of directives. Subnational authorities play a secondary, but increasingly important, role in the application of these measures. Their impact is greater on environmental and social policies, as it is also on public contract legislation. More decentralized states display higher levels of subnational involvement but, in these states, regional participation in national policy-making and a high number of regional authorities decrease the likelihood of finding subnational measures of transposition. There is also more subnational involvement in states with territories that have both an elected government as well as special arrangements regulating their relations with the EU. Finally, subnational involvement tends to prolong the process of transposition.
\end{abstract}

KEY WORDS Compliance; directives; federalism; implementation; regions; transposition.

\section{INTRODUCTION: REGIONALIZATION AND THE EU BETTER REGULATION AGENDA}

Regionalization has been on the increase in the European Union (EU) over the last two decades. ${ }^{1}$ According to a recently developed index (Hooghe, Schakel and Marks 2008), since the early 1990s, 13 EU states increased their regional authority, ${ }^{2}$ one country (Belgium) decreased it, and the remaining 13 member states made no change. The process of European integration could have indirectly contributed to these developments (Börzel 2002). Certainly, the EU tried over the years to deal with a growing mobilization of subnational authorities, which were pushing for more say in its decision-making process (Hooghe 1995). The most obvious measures were the establishment of the Committee of the Regions, the rewording in the Maastricht Treaty of Article 203 EC that allowed a member state to be represented in the Council of Ministers by a regional government, and the setting-up of procedures to safeguard the implementation of the subsidiarity principle (Committee of the Regions 2005).

Does this growing regionalization, in conjunction with the greater involvement of subnational actors in the EU policy process, pose a challenge for the 
achievement of the targets set by the 'better regulation' agenda? The main objective of this programme is to improve the quality of EU legislation by overhauling the process through which rules are created, implemented and revised (Hardacre 2008). Better rules facilitate correct functioning of the internal market and achievement of the growth and competitiveness goals of the Lisbon Strategy (Commission of the EC 2007). A policy analyst committed to attain a better regulatory environment cannot, therefore, ignore the role that subnational authorities (SNAs) play (Baliu 2008; Persson and Fandel 2007).

The increasing involvement of SNAs in the EU policy process is both an opportunity and a risk. Broader participation may be in line with the subsidiarity principle and represent a partial solution for the EU legitimacy problems. Additionally, consulting street-level implementers provides EU legislators and the Commission with a more realistic view of what is necessary and feasible on the ground (Tömmel 1998). Finally, it gives SNAs an opportunity to improve their knowledge of EU policy objectives, working methods and instruments, which are no longer considered an external imposition (Commission of the EC 2001:12-14).

But SNA involvement has its price, too. Their participation at the consultation stage inevitably multiplies the number of conflicting preferences that have to be aggregated. When a compromise is reached, it may often affect legal clarity. In implementation, SNAs do not, perhaps, possess an 'understanding of the EU policy process as a whole, which then enables them to have a clearer view of potential or actual infringements and the stance the Commission is likely to take' (Dimitrakopoulos and Richardson 2001: 339). Tensions may arise when an EU law envisages a single implementing authority but the competence for dealing with a particular issue is not the exclusive attribute of the national level (Mandelkern Group on Better Regulation 2001: 50). Additionally, the Commission cannot exert pressure directly on SNAs, because it is the central government which, under Article $226 \mathrm{EC}$, is responsible vis-à-vis the EU for infringements committed by its subnational authorities. In sum, SNA involvement represents yet another point in the policy cycle where slippages or outright failures could occur, thus increasing the implementation deficit that is said to afflict the EU (Mastenbroek 2005).

In light of this discussion, the focus of this article is the formal ${ }^{3}$ subnational involvement in the implementation of EU regulatory policies that take the form of directives. Whereas there is evidence that the political profile of subnational actors in the EU is on the rise, this issue has been studied only marginally. Academic works have dealt primarily with two topics: the role of regional institutions in the design of policies and in the management of structural funds. The next section briefly reviews these contributions and presents an overview of those works on implementation and compliance that assess the impact of SNAs. The following section looks at a stage of the implementation process that is directly relevant to the better regulation agenda: the transposition of EU directives. This part of the article presents evidence of SNA involvement in the transposition of directives across time, policy sectors and member states, 
employing a dataset on national transposition processes covering the time-span of 1978 to 2004. Thereafter, the article explains the variance in SNA involvement and evaluates its consequences in terms of timeliness of transposition.

\section{SUBNATIONAL AUTHORITIES AS POLICY-TAKERS: THE IMPLEMENTATION OF EU REGULATORY POLICIES}

The literature covering the regional activities in the EU policy process may be arranged following a widely used partition between upstream (policy formulation and decision) and downstream (implementation) policy processes. With regard to the role of regions as policy-makers, some researchers have investigated the channels available to regional authorities which wish to project their preferences on the European stage, namely their lobbying practices and their representation in EU institutions such as the Committee of the Regions or the Council of Ministers (e.g., Bomberg and Peterson 1998; Tatham 2008). Another group of researchers have studied the formation and effectiveness of inter-regional associations, formed both within and across the member states (e.g., Weyand 1997). Finally, others have proposed to investigate those channels of intermediation with the EU that are presided by central state authorities (e.g., Jeffery 2000).

With regard to the downstream side of the policy process, most works have focused on the management of EU regional funds, namely on redistributive policies. These studies have assessed the policy and institutional outcome of the implementation of these funds (e.g., Bache 2004; Hooghe 1996). The prevalence of this type of research is not a surprise. There is no other policy sector where regional authorities have come to play a comparable role. Nevertheless, subnational authorities are also involved in the implementation of EU legislation, which has a predominantly regulatory nature. This area, therefore, needs further investigation. The remainder of the section will provide an overview over those works whose main object of study is, broadly, implementation and compliance but which take into account the impact of SNAs as well.

In the 1980s, scholars studying the implementation of the single market programme already recognized the importance of streamlining the co-ordination between central and subnational administrations in federal or regional states, such as Belgium, Germany, Italy and Spain. Siedentopf and Ziller (1988: 45, 60), for instance, observed that these procedures were not yet fully developed in these states and that the allocation of responsibilities between governmental levels was unclear, especially in Italy and Belgium, where decentralization was relatively recent. ${ }^{4}$ They also observed that 'the incorporation process reflects a certain unwillingness of the subnational levels to comply with ... measures on whose substance they had had no influence' (Siedentopf and Ziller 1988: 45).

The second wave of researchers focused on the goodness-of-fit hypothesis, which argues that the adaptation pressure exerted by the EU on member states is determined by the degree of fit between EU legal obligations and either existing national paradigms and administrative traditions (institutional 
misfit) or domestic policy instruments (policy misfit) (e.g., Börzel and Risse 2003; Knill and Lenschow 1998; see the reviews by Mastenbroek [2005] and Treib [2008]). Knill and Lenschow (1998), for instance, argue that national administrative traditions, comprising, among other things, the vertically and horizontally distributed administrative competences, obstruct the implementation of environmental directives, particularly when they call for the creation of an agency whose mandate overlaps regional competence or requires the establishment of regional co-ordination structures, which were thus far nonexistent.

Haverland (2000), however, has a counterargument to this reasoning. $\mathrm{He}$ argues that the opposition to the packaging directive by Länder, channelled through the Bundesrat, was the central reason for Germany's poor implementation of the directive compared to that of the UK and the Netherlands (where the misfit with the directive was higher). Germany's strong bicameralism and federalism provided domestic interests hostile to the directive with a veto power. Yet, in their research on transport policy in Germany, Italy, Netherlands, UK and France, Hèritier et al. (2001) conclude that a consensual political leadership may offset the potential obstacles to policy change associated with a strong subnational tier of government.

Besides the institutional misfit, state-region intergovernmental relations may play a role as well. According to Börzel (1998), the better performance of Germany, compared to that of Spain, in the implementation of some environmental policies may be explained by its co-operative federalism, which favoured the sharing of implementation costs and the participation of subnational authorities, as opposed to the Spanish competitive regionalism that relied on burden shifting and limited involvement.

Against the backdrop of this qualitative literature, a few large-N studies have analysed how the distribution of powers across different levels of government impacted on compliance performances. The results obtained are mutually contradictory. Mbaye (2001) shows that member states with greater regional autonomy are more likely to infringe EU law, but Giuliani (2003) and Jensen (2007) fail to confirm this finding. ${ }^{5}$ Linos $(2007)$ and Thomson $(2007,2009)$ find that decentralized countries take longer time to comply with social policy directives. Giuliani (2003) and Haverland and Romeijn (2007), however, find no significant association between federalism and delay in transposition. What accounts for these differences? In some cases, the object of investigation - infringement or delay - and its measurement differ, while in others the research is limited to a single policy area or a few countries. Also, these works employ different indexes of regional autonomy. Nevertheless, in a recent comprehensive analysis of all the directives adopted between 1986 and 2002, König and Luetgert (2009) confirm the association between federalism and delay.

In conclusion, since the mid-1980s, the study of transposition consolidated itself into an important subfield of EU research (Treib 2008). These works have the merit of drawing attention to the timely and correct transposition of EU directives, which constitutes a decisive prerequisite for the realization of the Lisbon Agenda. Nevertheless, despite the recent interest of the Commission 
(under the better regulation initiative) and of other institutional actors, such as the Scottish Parliament (European and External Relations Committee 2008), scholars have so far mostly neglected the subnational dimension.

The next section describes the pattern of formal involvement of SNAs across time, member states and sectors using an original dataset that allows one to discriminate between the national and the subnational measures employed to transpose a large sample of directives.

\section{THE INVOLVEMENT OF SNAS IN THE TRANSPOSITION OF EU DIRECTIVES: DESCRIPTIVE STATISTICS}

We have collected information on 11,859 national measures transposing 733 directives adopted in 15 member states between December 1978 and December 2004 from the CELEX database of the European Union. ${ }^{6}$ The directives were selected randomly and the implementing measures classified based on who adopted them: national parliaments; the cabinet or other executive institution, such as ministries or national agencies; or subnational authorities. We excluded national measures that have been adopted on or prior to the date of adoption of the directive, those without a date of adoption and, for those member states joining the EU after 1978, the directives which predated the accession date. $^{7}$

We considered measures taken only by subnational authorities with an elected assembly that appoints a regional executive. ${ }^{8}$ These include mainly the Austrian and German Länder, the Danish and Swedish counties, the Dutch provinces, the Finnish regions, the Italian provinces and regions and the Spanish autonomous communities. They also include the French regions since 1982, the Greek prefectures since 1984, the Irish county councils and, since 1994, regional authorities, the Belgian provinces and, as they became more representative during the 1980s, communities and regions, and finally, the British counties, when these existed, and its devolved administrations as they increased powers in the 1990s. Table 1 provides an overview of the number of directives and subnational measures per member state and some examples of subnational measures present in our dataset.

The first important finding is that formal subnational involvement in the transposition of EU directives has been quite a limited phenomenon so far. We have found at least one subnational act in only 4.3 per cent of the processes of transposition. Considering only the states listed in Table 1, this figure rises to 7.4 per cent. Nonetheless, there has been an increase in subnational participation over the years. SNAs were involved in 2.8 per cent of transposition processes up to the mid-90s. The figure has subsequently moved up to 6.3 per cent, predominantly because of the enlargement to Finland and Austria and devolution in Britain. ' Subnational involvement could also have been underestimated, because, at least for the directives adopted after 2000, our data could be rightcensored in a way that it is biased against subnational measures, which, as will be shown later, generally take longer time to be adopted. 
Table 1 Measures of subnational authorities

\begin{tabular}{|c|c|c|c|}
\hline Member state & $\begin{array}{l}\text { No. } \\
\text { directives }\end{array}$ & $\begin{array}{l}\text { No. of SNA } \\
\text { measures }\end{array}$ & Examples of subnational measures \\
\hline Austria & 214 & 235 & $\begin{array}{l}\text { Landesgesetz, Verordnung der } \\
\text { Landesregierung }\end{array}$ \\
\hline Belgium & 575 & 192 & $\begin{array}{l}\text { Arrêté du Gouvernement (Wallon, } \\
\text { Flammand), Arrêté du } \\
\text { Gouvernement de la Communauté } \\
\text { française }\end{array}$ \\
\hline Finland & 235 & 90 & $\begin{array}{l}\text { Landskapslag, Ålands } \\
\text { Landskapsstyrelses Beslut, } \\
\text { Landskapsförordning }\end{array}$ \\
\hline Germany & 474 & 169 & Landesgesetz, Landesverordnung \\
\hline Italy & 566 & 12 & $\begin{array}{l}\text { Legge Regionale, Decreto del } \\
\text { Presidente della Giunta Regionale }\end{array}$ \\
\hline Netherlands & 496 & 3 & Provinciale Verordening \\
\hline Portugal & 491 & 3 & $\begin{array}{l}\text { Decreto Legislativo Regional, } \\
\text { Decreto regulamentar regional } \\
\text { (Madeira, Açores) }\end{array}$ \\
\hline Spain & 502 & 5 & $\begin{array}{l}\text { Ley de la Comunidad Autónoma, } \\
\text { Orden de la Comunidad Autónoma }\end{array}$ \\
\hline United Kingdom & 528 & 213 & Act, Regulation, Order \\
\hline
\end{tabular}

Note: We found 9,704 executive, 1,233 legislative and 922 subnational measures. No subnational measures were found for Denmark (499 directives), France (538), Greece (527), Ireland (536), Luxembourg (558) and Sweden (208).

We find, therefore, some evidence for the claim of a gradually increasing formal role for SNAs (Baliu 2008; Commission of the EC 2001; Persson and Fandel 2007), but this involvement remains a minor cause of the EU transposition deficit. One could even argue for more subnational participation in policy formulation, given the rather limited role in implementation.

Figure 1 illustrates SNA involvement across member states, that is, the percentage of the national transposition processes of the sampled directives that include at least one subnational measure. There are indeed some unexpected results. In Finland, more than one in four directives lists at least one SNA act among the national transposition measures. However, this is unrelated to the Finnish regions. It is solely owing to the measures taken by the government of the Aland Islands, the autonomous and directly elected province of Finland, which enjoys a special status and is exempted from some EU policies. On the other hand, it is somewhat surprising that Britain has the second-largest share of SNA measures. Besides the measures of the overseas territory of Gibraltar, which also enjoys a special status, the creation of devolved governments with significant policy competence in Wales, Scotland and Northern Ireland in the late 1990s strongly regionalized the process of transposition here. On the 


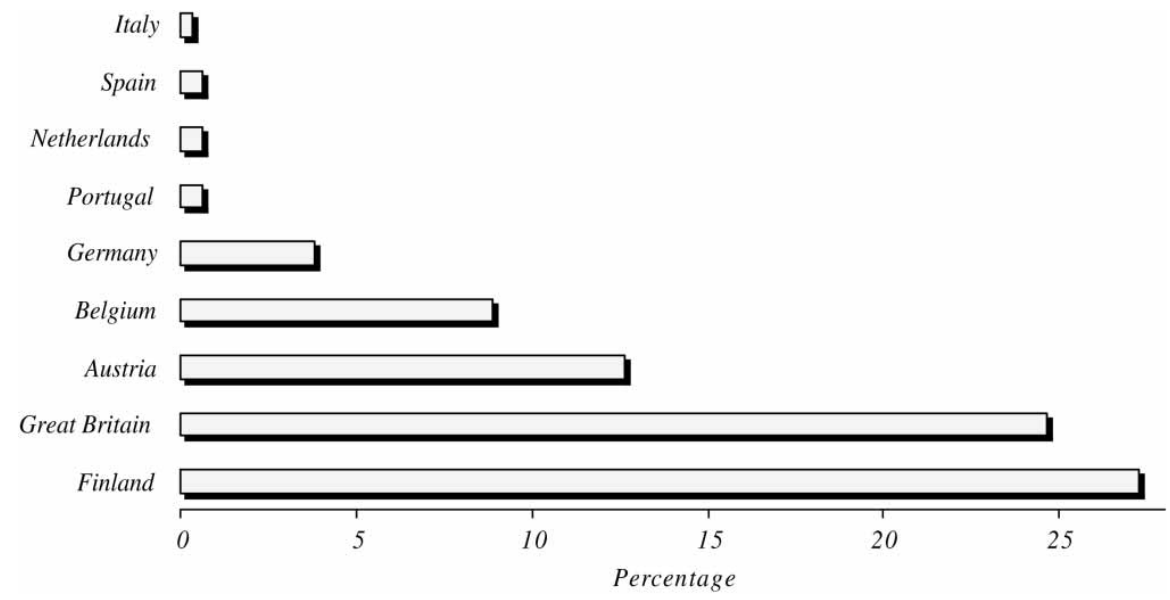

Figure 1 SNA involvement per member state

other hand, the presence of an upper chamber representing the regions (or states) could explain the lower involvement of SNAs in Germany, Austria and, to a lesser extent, Belgium, compared to that in Britain and Finland. Directives may be transposed through federal measures even when policies fall within regional competence.

It comes as no surprise that old or recent federal states, like Austria, Germany and Belgium, rank higher than the countries with strong regional authorities like Spain and Italy (interestingly, Dutch provinces appear to be as involved in transposition as Spanish or Italian regions). However, this difference cannot be attributed entirely to the more limited competence devolved in Spain and Italy. Here, national governments probably take the lead in transposing the directives if the distribution of policy responsibilities between central and regional authorities is unclear. But more importantly, the task of activating 20 regional legislative or executive procedures in Italy and 17 in Spain for a single directive may prove so burdensome that the central government, in consultation with regional actors via permanent bodies such as the Spanish conferencias sectoriales and the Italian conferenza stato-regioni, often takes the responsibility of initiating the whole process (Bindi and Cisci 2005).

In the case of Portugal, regions and districts have weak authority and institutions. As for the special territory of the Åland Islands in Finland, subnational measures are taken solely by the regional governments of the Azores and Madeira. Unlike Finland, however, and at least until the constitutional revision of 2004, these measures had to be preceded by acts of the central Portuguese authorities.

In conclusion, with the exception of Gibraltar, the Italian and Dutch provinces, the authorities most involved are from regions that belong to the Conference of European regions with legislative power (REGLEG). ${ }^{10}$ No subnational measures were found in the remaining member states. French regions, ${ }^{11}$ Greek prefectures, 
Taxation

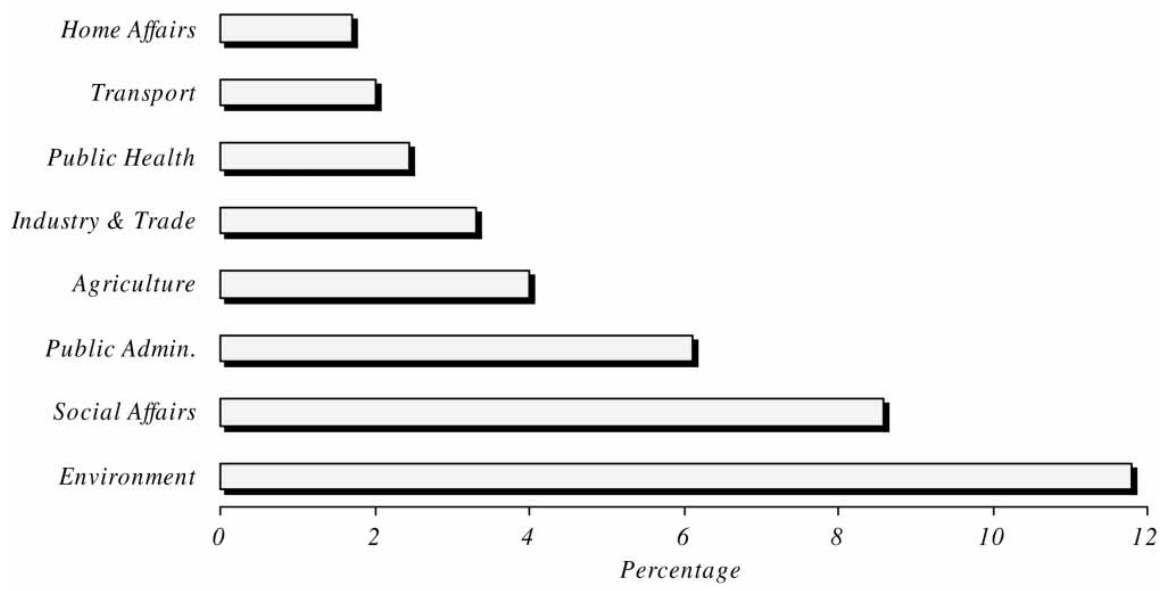

Figure 2 SNA involvement per policy area

Danish and Swedish counties, and Irish counties and regions do not seem to play any formal role in the transposition of the sampled directives. Also, there are no measures in Luxembourg, where there is no elected regional government.

Moving on to policy areas, Figure 2 illustrates considerable variance in SNA involvement here. The rather heavy participation in environmental policy can probably be explained by the strong territorial nature of this sector (see Brown 1999) - recall that the Fifth Environmental Action Programme in 1993 laid emphasis on shared responsibility, and advocated the involvement of stakeholders in improving policy effectiveness. The same applies to some measures in agriculture policy and to the directives regulating the tenders of public contracts.

Perhaps more surprising is the role of these authorities in the transposition of social policy directives that deal with protection of workers, working conditions and safety at work. But social policy is sometimes devolved to the lower tiers of government in countries where SNAs are important actors. Finally, it should not come as a surprise that areas that regulate taxation, home affairs, public health, market transactions and transport tend to exclude SNAs.

\section{EXPLAINING SUBNATIONAL INVOLVEMENT}

How does one explain these patterns of SNA participation in the transposition of directives? A natural expectation is that involvement is more likely in more decentralized countries. But this observation has to be qualified on at least two accounts. First, we should expect fewer subnational measures of transposition in decentralized states where regional governments can, directly or through their representatives, influence policy at the national level. In other words, where 
regional interests are taken into account in the national decision-making process, we are likely to see fewer regional measures. Second, regional transposition is likely to be unwieldy in decentralized states with a large number of subnational authorities. In these circumstances, we should expect national transposition, possibly sustained by co-ordination mechanisms such as state-regions committees, to replace formal SNA participation. ${ }^{12}$ In this section, we subject these two conditional hypotheses to an empirical test.

The dependent variable, subnational involvement, takes a score of one if at least one national implementing measure is adopted by a subnational authority, and zero otherwise. We have then selected two frequently used decentralization indices and the self-rule component of the regional authority index recently developed by Hooghe, Marks and Schakel (2008). The five-point ordinal scale of federalism and decentralization of Lijphart (1999: 189) ranks countries according to whether they are federal and decentralized, federal and centralized, semi-federal, unitary and decentralized, unitary and centralized. With the exception of Belgium, the index does not vary over time. Lane and Ersson's (1999: 187 ) index of institutional autonomy sums up four discrete components (federalism, special territorial autonomy, functional autonomy and local government discretion) producing a (time-invariant) five-point decentralization scale. The self-rule index recently developed by Hooghe et al. (2008; 2008) measures the authority exercised by a regional government over those living in its territory, and comprises four dimensions (institutional depth, policy scope, fiscal autonomy and representation) that are summed up as a 16-point index. Hooghe, Schakel and Marks (2008) produce a score for each regional reform from 1950 to 2006 .

To measure the influence that regional governments exercise at the national level, we employ the shared rule component of Hooghe, Marks and Schakel's (2008) regional authority index. Shared rule measures the authority exercised by a regional government or its representatives in the country as a whole and comprises four dimensions (law-making, executive control, fiscal control and constitutional reform) to produce a 10-point index for the 1950-2006 time period. In decentralized countries, we expect less subnational involvement in transposition as shared rule increases.

For the second expectation, we have counted, for each country and relevant time period, the number of SNAs at the highest tier of regional government, but above communes and municipalities, with an elected assembly that appoints a regional executive. ${ }^{13}$ For instance, until 1979, we have counted the 10 Belgian provinces and, as they increased representativeness from 1980 onwards, the regions and communities. In decentralized countries, we expect less subnational involvement in transposition as the number of SNAs increases.

We also include a set of control variables. Firstly, we add dummy variables for policies, as listed in Figure 2, using taxation and home affairs as the reference category. Second, as can be seen from the descriptive statistics, several member states have special relations with some territories across the world whose measures are listed in our dataset. We employ, therefore, special territory 
as a dummy variable that takes the value of one for member states with outermost regions or other special territories that only partially apply EU law and have an elected government. ${ }^{14}$ However, since Hooghe, Schakel and Marks's (2008) self-rule index specifically takes into account special autonomous regions, whereas it is unclear whether other indicators do, we exclude this control variable in the regression with this index.

As directives are adopted at the supranational level and then transposed by the member states, the structure of our dataset appears hierarchical. Policy dummies are directive-level observations, while the three decentralization indices, shared rule, the number of SNAs and special territory, are country-level observations nested into the directive level. To assess whether there is significant variation in the probability of subnational involvement at the directive level, we estimated a two-level random effects analysis of variance (ANOVA) model. ${ }^{15}$ The coefficient of the directive-level variance component is 0.16 with a standard error of 0.015 (state-level, $\mathrm{N}=6,947$; directive-level, $\mathrm{N}=733$ ). This value is greater than zero at a significance level above 0.01, implying that a significant proportion of the variance in the probability of subnational involvement is attributable to differences between directives, supporting the expectation that our dataset is structured into two levels. We therefore estimate two-level probit models with random-intercept and robust standard errors for data clustered at the state level to account for correlation within each country.

Table 2 illustrates the regression results. The substantive interpretation of the coefficients of a probit model, especially if it contains interaction terms, is not straightforward. For instance, the marginal effect of the decentralization indices on the probability of subnational involvement depends on the values of the conditioning (i.e., shared rule and the number of $S N A$ s) as well as dummy variables. The three coefficients of the decentralization indices in Table 2 are positive and significant as expected, indicating that greater decentralization increases the likelihood of subnational involvement when shared rule equals zero and subnational authorities do not exist. This, however, is substantively less meaningful because only France, Greece and Luxembourg display these features but none of them has subnational transposition measures. Nevertheless, suffice it to say that the majority of the countries with no subnational measures display below average levels of decentralization, while the majority of the top five countries listed in Figure 1 have above average levels of decentralization. ${ }^{6}$

To test the validity of the first conditional hypothesis, we mapped in Figure 3 the marginal effect and the 95 per cent confidence intervals of an increase in shared rule (specifically six units, slightly less than two standard deviations, which is the difference between Spain and Germany) on the likelihood of subnational involvement in the transposition of an environmental directive across the different degrees of decentralization. ${ }^{17}$ The top two charts conform to the expectation. In more decentralized countries, we are less likely to find subnational measures if regional authorities have greater influence in the country as a whole. Providing real-life examples is difficult because countries simultaneously vary along the degree of shared rule and several other 
Table 2 The determinants of formal SNA involvement in transposition. Dependent variable: subnational involvement

\begin{tabular}{|c|c|c|c|}
\hline Parameters & I & II & III \\
\hline \multicolumn{4}{|l|}{ Fixed Effects } \\
\hline Intercept & $-5.017(0.381)^{* *}$ & $-5.354(0.386)^{* *}$ & $-3.737(0.392)^{*}$ \\
\hline \multicolumn{4}{|l|}{ Decentralization indices: } \\
\hline Lijphart & $0.829(0.077)^{* *}$ & - & - \\
\hline Lane and Ersson & - & $0.843(0.078)^{* *}$ & - \\
\hline Self rule (Hooghe et al.) & - & - & $0.070(0.005)^{* *}$ \\
\hline Shared rule & $0.131(0.031)^{* *}$ & $-0.244(0.081)^{* *}$ & $0.014(0.027)$ \\
\hline Number of SNAs & $0.069(0.006)^{* *}$ & $0.060(0.005)^{* *}$ & $0.067(0.004)^{* *}$ \\
\hline Shared rule $\times$ Lijphart & $-0.041(0.007)^{* *}$ & - & - \\
\hline$\times$ Lane and Ersson & - & $0.033(0.022)$ & - \\
\hline$\times$ Self rule (Hooghe et al.) & - & - & $-0.0002(0.002)$ \\
\hline No. of SNAs $\times$ Lijphart & $-0.051(0.005)^{* *}$ & - & - \\
\hline$\times$ Lane and Ersson & - & $-0.039(0.005)^{* *}$ & - \\
\hline$\times$ Self rule (Hooghe et al.) & - & - & $-0.006(0.0004)^{* *}$ \\
\hline Special territory & $1.136(0.070)^{* *}$ & $1.328(0.091)^{* *}$ & - \\
\hline Agriculture & $1.071(0.362)^{* *}$ & $1.098(0.347)^{* *}$ & $1.012(0.385)^{* *}$ \\
\hline Environment & $1.694(0.410)^{* *}$ & $1.721(0.378)^{* *}$ & $1.580(0.373)^{* *}$ \\
\hline Industry and trade & $0.962(0.398)^{*}$ & $0.975(0.328)^{* *}$ & $0.892(0.351)^{*}$ \\
\hline Public administration & $1.238(0.472)^{*}$ & $1.240(0.558)^{*}$ & $1.251(0.588)^{*}$ \\
\hline Public health & $0.730(0.569)$ & $0.732(0.278)^{*}$ & $0.689(0.527)$ \\
\hline Social affairs & $1.545(0.396)^{* *}$ & $1.634(0.429)^{* *}$ & $1.426(0.365)^{* *}$ \\
\hline Transport & $0.700(0.302)^{*}$ & $0.709(0.403)$ & $0.667(0.401)$ \\
\hline \multicolumn{4}{|l|}{ Random Effects } \\
\hline Variance, intercept & $0.123(0.044)^{*}$ & $0.144(0.031)^{*}$ & $0.113(0.040)^{*}$ \\
\hline Log-likelihood & -1039.834 & -1019.329 & -1090.719 \\
\hline
\end{tabular}

Notes: Two-level probit regressions with random-intercept and robust standard errors clustered on country level. $\mathrm{N}=6,947$ (directivelevel $\mathrm{N}=733$ ). ${ }^{* *}=\mathrm{p}<0.01,{ }^{*}=\mathrm{p}<0.05$. Policy reference category: taxation and home affairs. 

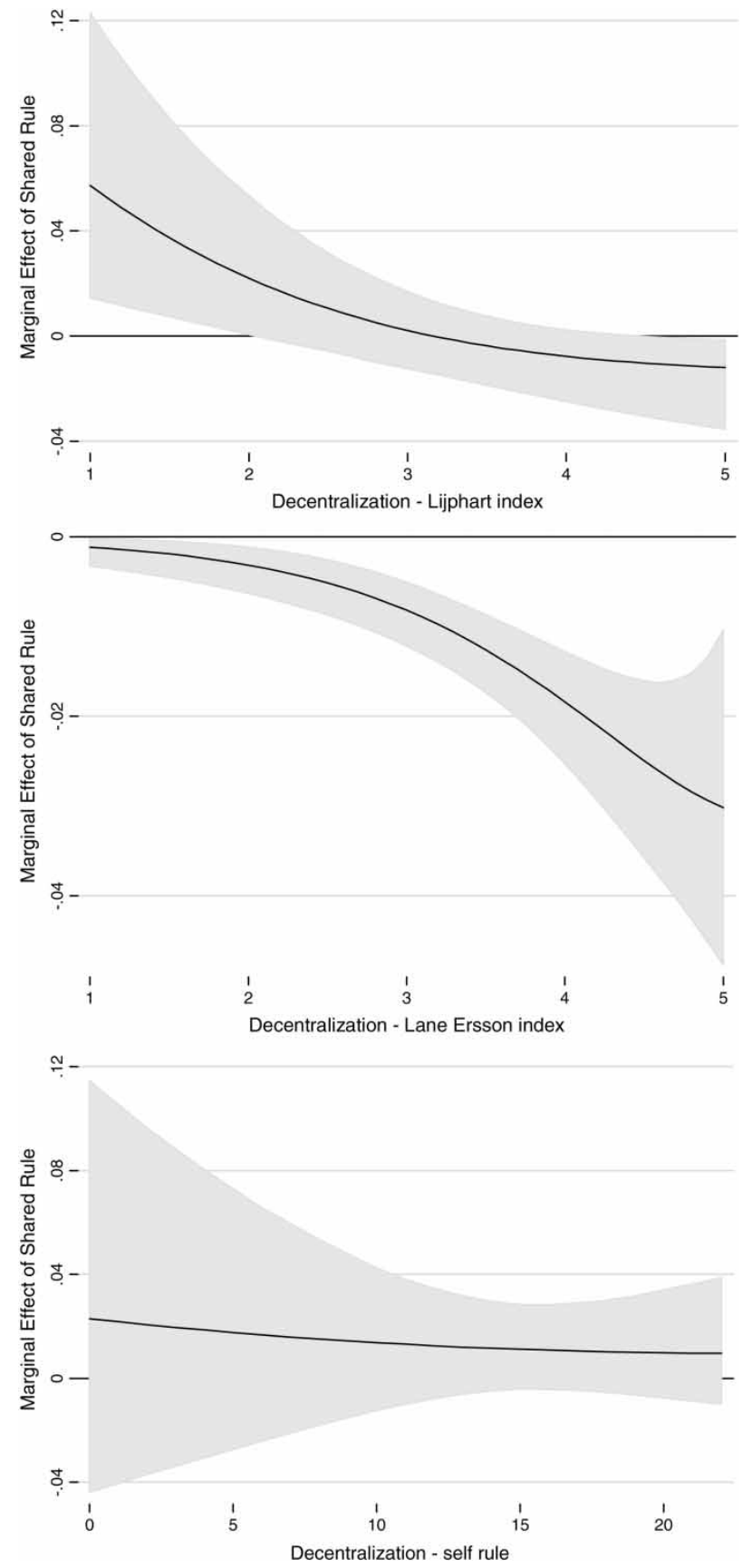

Figure 3 The impact of shared rule on subnational involvement at different levels of decentralization 
dimensions. Nevertheless, we would be between 2 and 2.5 per cent less likely to find subnational measures of transposition if a decentralized country like Austria increases the degree of shared rule by a standard deviation. This is equivalent to the difference between Austria and the similarly decentralized Belgium, and this may account for the more limited involvement in transposition of Belgian communities and regions as compared to Austrian Länder, despite fewer SNAs in Belgium. These results should be interpreted somewhat cautiously, however, because the expectation finds no support when self-rule is used as the measure of decentralization.

The second hypothesis is more convincingly validated, as can be seen from Figure 4. The figure illustrates the marginal effect and confidence intervals of an increase in the number of subnational authorities (specifically 11 units, slightly less than a standard deviation, which is equivalent to the difference between Austria and Italy) on the likelihood of subnational involvement across the degrees of decentralization. In more decentralized countries, we are less likely to find subnational measures as the number of SNAs increases. If the number of Belgian SNAs increases from the current 5 to 16 (as in Spain), we would be 10.3 to 19.2 per cent less likely to find subnational measures in Belgium.

With regard to the remaining factors, we are 11.8 to 15.8 per cent more likely to find subnational measures when states have territories that enjoy a special relationship with the EU. These regional authorities need to adopt and communicate to the EU their own measures, which are likely to differ from those of their national governments. Finally, as already seen in Figure 2, environmental and social policy directives are 3.0 to 9.6 per cent more likely to involve SNAs in transposition. Measures on public administration, agriculture and industry are also significantly more likely to involve SNAs than do the home affairs and taxation directives; however, it is less so in the case of public health and transport directives.

\section{THE CONSEQUENCES OF SUBNATIONAL INVOLVEMENT}

What are the consequences of involving subnational authorities in the transposition of directives? Does SNA involvement prolong transposition and compliance with EU law? In this section, we take as our unit of analysis the national measures transposing the directives and we analyse the timing of their adoption. As several observations have only the year of adoption, our time variable, transposition, counts the number of calendar years that elapsed between the adoption of the directive and the adoption of the national measure, starting with the value of one if the two adoptions fall in the same calendar year. To avoid the risk of selection bias (Box-Steffensmeier and Jones 2004: 19), directives without national implementing measures in 2006 are treated as right-censored observations. A total of 3,053 national transposition processes fall into this category.

As explained earlier, the implementing measures have been classified depending on who adopted them: the legislature; the executive; or subnational 

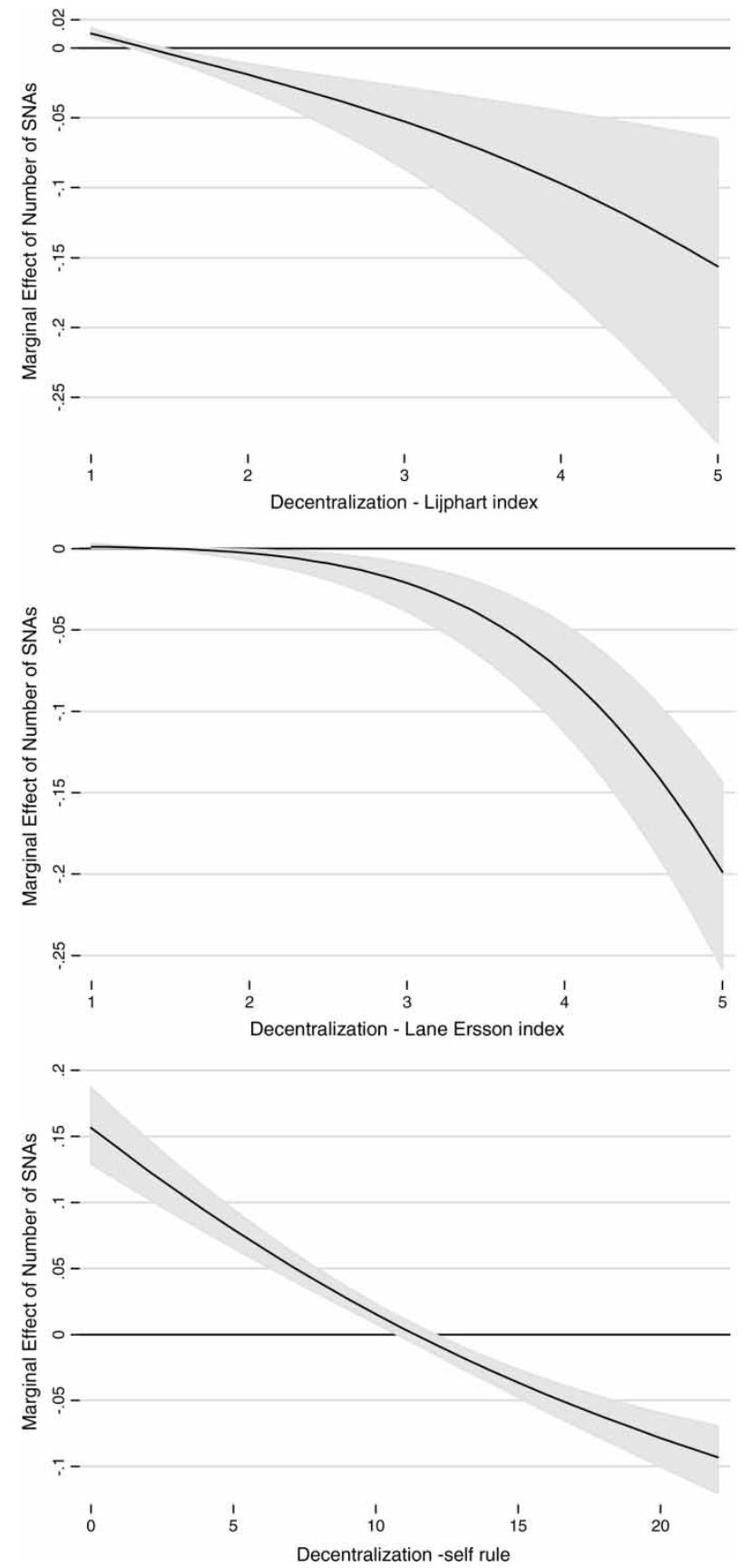

Figure 4 The impact of the number of SNAs on subnational involvement at different levels of decentralization 
authorities. This classification allows us to generate two dichotomous explanatory variables, subnational measure for implementing acts adopted by a subnational authority, and legislative measure for those adopted by the national parliament, leaving executive acts as the reference category.

The former variable is measured at the level of the national acts transposing a directive in a country. Earlier works that analyse the implications of decentralization for compliance employ coarser indices that do not vary across the directives implemented within a country (Giuliani 2003; Haverland and Romeijn 2007; König and Luetgert 2009; Linos 2007; Thomson 2007, 2009).

Legislative measure instead allows us to control for the impact of parliamentary involvement on transposition. As in the case of decentralization, the results do not seem to point in the same direction. Berglund et al. (2006), for utilities and food safety, and Haverland and Romeijn (2007), for social policy, do not find any association between parliamentary involvement and delay, while, in their more comprehensive study, König and Luetgert (2009) find a significant negative relation between legislative participation and delay. In the Netherlands, involvement delays transposition initially but accelerates it later (Mastenbroek 2003). However, in Italy (Borghetto et al. 2006) and in maritime policy (Steunenberg and Kaeding 2009), it behaves in the opposite way. ${ }^{18}$

We include other control variables that are used in the literature as well. Commission directive is a dummy variable that takes the value of one for a Commission directive and zero for a Council or Parliament (where involved) directive, while amending directive takes the value of one if the directive amends an existing EU law. Deadline is a time-varying covariate that takes the value of one in risk periods where the deadline for transposing a given directive has expired. These factors should accelerate transposition (Borghetto et al. 2006; Mastenbroek 2003; Steunenberg and Kaeding 2009; c.f. Haverland and Romeijn 2007). Finally, we include dummy variables for each member state.

The transposition of a directive may involve the adoption of more than one national measure without a predetermined sequence. The primary interest of this study is in the relationship between the covariates and transposition, and no explicit inferences need to be made about duration dependency. Therefore, as recommended by Box-Steffensmeier and Jones (2004), we employ the Cox proportional hazards model with robust standard errors clustered on the directives. $^{19}$

Table 3 illustrates the regression results, while Figure 5 maps the effect of the covariates on the likelihood of adopting national measures over a given time period after the adoption of the directive. The most important finding is that involvement of SNAs decreases the hazard ratio; in other words, it prolongs the process of transposition. Subnational measures are two-and-a-half times less likely of being adopted within the same calendar year of adoption of the directive than other types of national implementing measures. The change in the hazard rate becomes positive; that is, subnational measures are more likely to be adopted, only after more than two years. But only 36 per cent of national measures are adopted after this time period, which is well beyond the mean 
Table 3 Involvement of SNAs and timing of adoption of national implementing measures. Dependent variable: transposition

\begin{tabular}{|c|c|}
\hline \multicolumn{2}{|l|}{ Covariates } \\
\hline Subnational measure & $-0.896 * *(0.220)$ \\
\hline Subnational measure $* \ln (\mathrm{t})$ & $0.929 * *(0.146)$ \\
\hline Legislative measure & $-0.036 \quad(0.118)$ \\
\hline Legislative measure * $\ln (\mathrm{t})$ & $0.489 * *(0.086)$ \\
\hline Commission directive & $1.135 * *(0.103)$ \\
\hline Commission directive ${ }^{*} \ln (\mathrm{t})$ & $-0.671^{* *}(0.092)$ \\
\hline Amending directive & $0.361^{* *}(0.137)$ \\
\hline Amending directive ${ }^{*} \ln (\mathrm{t})$ & $-0.387^{* *}(0.104)$ \\
\hline Deadline & $0.109 \quad(0.171)$ \\
\hline Deadline ${ }^{*} \ln (\mathrm{t})$ & $-0.156 \quad(0.175)$ \\
\hline Belgium & $-0.175^{*}(0.074)$ \\
\hline Denmark & $0.104 \quad(0.077)$ \\
\hline Finland & $0.302 * *(0.074)$ \\
\hline France & $0.030 \quad(0.070)$ \\
\hline Germany & $-0.200^{*}(0.081)$ \\
\hline Greece & $-0.160 * \quad(0.072)$ \\
\hline Ireland & $-0.112 \quad(0.072)$ \\
\hline Italy & $-0.143 \quad(0.073)$ \\
\hline Luxembourg & $-0.112 \quad(0.072)$ \\
\hline The Netherlands & $-0.031 \quad(0.076)$ \\
\hline Portugal & $0.022 \quad(0.069)$ \\
\hline Spain & $0.152 * \quad(0.074)$ \\
\hline Sweden & $0.131 \quad(0.074)$ \\
\hline United Kingdom & $0.074 \quad(0.076)$ \\
\hline Log-likelihood & -108065.71 \\
\hline
\end{tabular}

Notes: Cox proportional hazard model. ${ }^{* *}=p<0.01,^{*}=p<0.05$. Robust estimators, standard errors in parenthesis adjusted for clustering on directives. Breslow method for ties. Subjects (N) 15,153, failures (transposed directives) 12,100. Reference category for types of implementation acts: executive measures. Member state reference category: Austria.

deadline of one year for transposition. This evidence lends support, at the finer level of the single national implementing measure, to the broader association between federalism and delay (König and Luetgert 2009; Linos 2007; Thomson 2007, 2009).

Legislative measures, on the other hand, do not seem to make a significant difference initially but, after a year, they speed up transposition and are increasingly more likely to be adopted than other type of implementation acts (86 per cent of the observations fall within this time frame). This lends conditional support to other works. The initial insignificance of the coefficient is in line with the analyses of Berglund et al. (2006) and Haverland and Romeijn (2007), but, over time, it confirms the accelerating impact found by König 

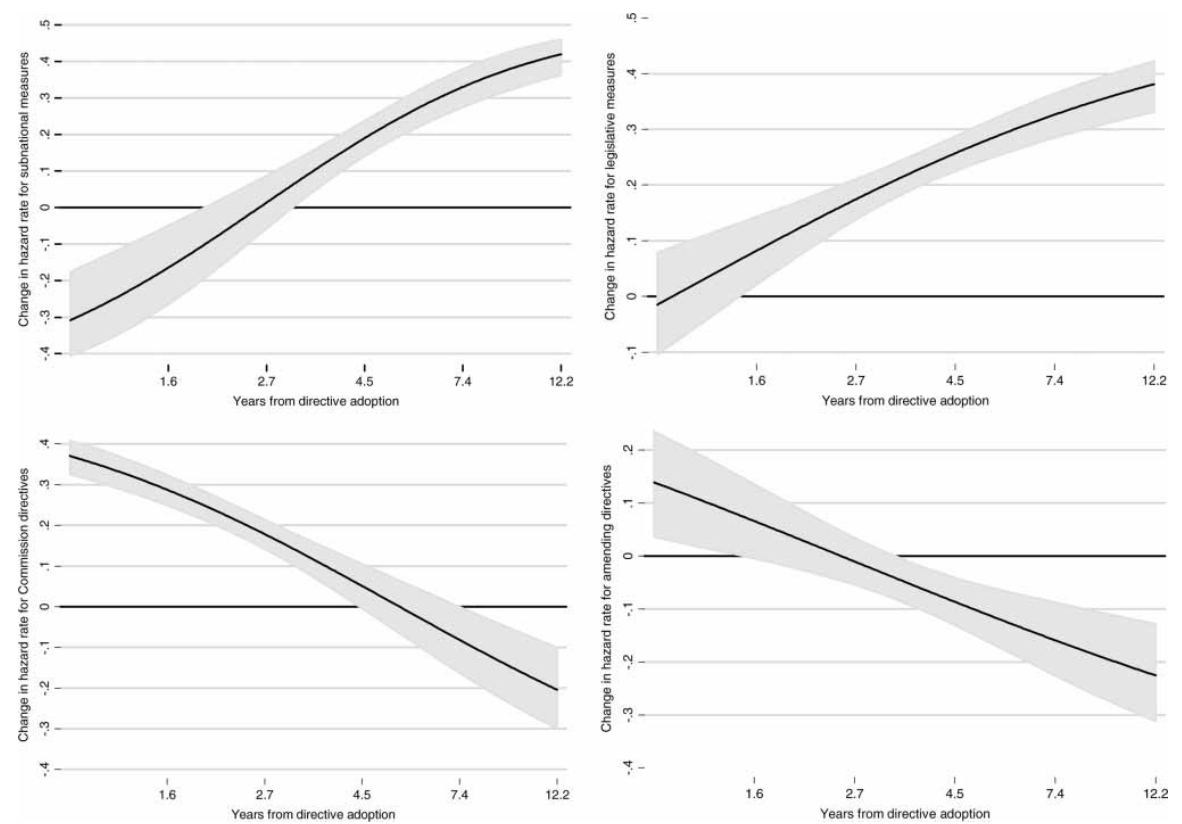

Figure 5 Effects of covariates on the timing of adoption of national implementing measures

and Luetgert (2009), whose results, however, are not conditional on time, and, especially, Mastenbroek (2003).

As expected, Commission directives are three times more likely of being transposed in the same calendar year of their adoption than are the Council (and Parliament) directives. The change in the hazard ratio decreases, but remains significant and positive for the next three years. Also in line with previous studies, amending directives are almost one-and-a-half times more likely of being transposed within the same calendar year of their adoption than the non-amending measures are. The change in hazard ratio turns significantly negative in both cases, but this occurs only quite a few years after adoption. This is substantively irrelevant to more than 80 per cent of the sample. The last notable result is the irrelevance of the deadline covariate. Passing the transposition deadline does not seem to speed up implementation.

\section{CONCLUSION}

Regionalization expanded across the European Union in the last two decades, and several institutional innovations were made at the EU level to accommodate regional demands for more influence on supranational policy-making. So far, the focus of academic work has predominantly been on the role of SNAs in the formulation and implementation of EU regional policy. This bias is 
addressed in this article by investigating the involvement of subnational authorities in the implementation of regulatory policies, specifically in the transposition of directives.

Subnational authorities play a secondary but increasingly important formal role in the implementation of these measures. Their influence is greater on environmental and social policies, as well as on public contract legislation. Moreover, some subnational measures have been found transposing directives on other policy fields, such as agriculture, industry and trade. Although more decentralized states display higher levels of subnational involvement, regional participation in national policy-making and a large number of regional authorities decrease the likelihood of finding subnational measures of transposition. Furthermore, there is more subnational involvement in states with territories that have both an elected government and special relations with the EU. Finally, in light of the better regulation agenda, subnational involvement tends to prolong the process of transposition, especially if new Council (and Parliament) directives need transposition.

In conclusion, the study of the role of subnational authorities in implementation is a promising research avenue. For instance, closer attention should be paid to SNA involvement when the responsibility for transposition lies formally at the national level. Last but not least, the issue confronts policy-makers with an important trade-off. On the one hand, greater SNA involvement is welcome to the extent that it increases participation and may improve policy design. On the other hand, this participation may jeopardize the creation of a level playing field by, for instance, prolonging transposition. After all, a free lunch does not seem to exist in politics either.

Biographical notes: Enrico Borghetto is Research Fellow in Political Science at the University of Milan. Fabio Franchino is Associate Professor in Political Science at the University of Milan and Research Fellow at URGE (Research Unit on European Governance) of the Collegio Carlo Alberto, Turin.

Addresses for correspondence: Enrico Borghetto, Dipartimento di Studi Sociali e Politici, Facoltà di Scienze Politiche, Università degli Studi di Milano, Via Conservatorio 7, 20122 Milan, Italy. email: enrico.borghetto@ unimi.it/Fabio Franchino, Dipartimento di Studi Sociali e Politici, Facoltà di Scienze Politiche, Università degli Studi di Milano, Via Conservatorio 7, 20122 Milan, Italy. email: fabio.franchino@unimi.it

\section{ACKNOWLEDGEMENTS}

Fabio Franchino would like to thank the Economic and Social Research Council and the Nuffield Foundation for financial support of the project on 'Compliance with EU Law: Explaining the Transposition of EU Directives', and the University of Milan for funding under the Programma dell'Università per la Ricerca. The authors received valuable comments on this paper from 
Alessia Damonte and the participants at the seminar of the Department of Political Science of the Institute of Advanced Studies in Vienna, as well as from two JEPP referees.

\section{NOTES}

1 Regionalisation is a process of power decentralisation from the state to a regional authority defined as a 'territorial entity situated between the local and national levels which has a capacity for authoritative decision making' (Marks et al. 2008: 113). In this work, the terms region and subnational authority are used interchangeably. Additionally, although the empirical section of this work is centred solely on the European Community pillar of the Treaty on European Union, the terms European Union and EU are used throughout, instead of European Community.

2 These are the Czech Republic, Finland, Greece, Hungary, Ireland, Italy, Lithuania, the Netherlands, Poland, Romania, Slovakia, Spain and the UK.

3 Involvement is formal when SNAs directly adopt national measures of implementation. It is informal if SNAs are merely consulted by central state authorities.

4 See also Rhodes (1986) and, for a recent similar argument related to the divergent transposition performances of unitary (Denmark) and federal (Belgium) states, Bursens (2002).

5 The results reported by Lampinen and Uusikylä (1998) are more difficult to interpret. The variable 'political institutions' is significantly associated with the failure to implement directives. But this is an index composed of 13 factors; it is therefore difficult to discern the impact of regional autonomy, which is one of the building blocks, from that of other components.

6 CELEX was no longer accessible after this cut-off point. Its content was migrated to the EUR-Lex database, available at http://www.eur-lex.europa.eu. The CELEX manual states that parts of the database are incomplete (e.g., sector 5 on preparatory acts before 1984) but this does not apply to the two sectors from which information was collected (sector 5 on secondary legislation and sector 7 on national implementing measures). For instance, the database lists 341 directives adopted in the five years prior to 1984 and 410 directives in the following five years. A mere difference of 70 directives (14 directives per year) between the period of 'Eurosclerosis' (pre-1984) and that of implementation of the single market programme (between 1984 and 1988) does not seem to indicate that the record is incomplete before 1984. See König and Luetgert (2009: 170-2) for a discussion on the reliability of this database.

7 From an initial random sample of 821 directives, 733 directives display at least one national implementing measure adopted in at least one member state after the date of adoption of the directive. This sample is quite representative of the Eur-Lex database. We have 314 Commission directives (38.6 per cent), while the database lists 872 Commission directives out of a total of 2,358 directives adopted in the same time period (37 per cent); 258 and 262 are agricultural and internal market measures respectively (31.4 and 31.9 per cent) compared to 769 and 914 (32.6 and 38.9 per cent) respectively in the database.

8 In other words, authorities with a representation score of at least 1,1 in the index developed by Hooghe, Marks and Schakel (2008).

9 Had the observations gone further back to the 1970s, one might have observed a rise in subnational involvement following the establishment of the Belgian communities and regions. On the other hand, it is difficult to speculate on the consequences of the last two enlargements on subnational involvement. Six of the twelve new member 
states display some degree of regional authority (Hooghe, Schakel and Marks 2008), but none has joined REGLEG (see Note 10).

10 REGLEG is an association of 73 regions with legislative power across eight member states (Austria, Belgium, Finland, Germany, Italy, Portugal, Spain and the UK).

11 Eight French arrêtés préfectoral transposing Council Directive 82/883 are considered national executive measures because they were issued by prefects who are central state representatives in a department or region.

12 Of course, these dynamics are not at work in more centralized countries where one simply expects less subnational involvement.

13 In other words, with a representation score of at least 1,1 (Hooghe, Schakel and Marks 2008).

14 These are Finland (Åland), France (French Guiana, Guadeloupe, Martinique), Germany (Büsingen am Hochrhein, Heligoland), Great Britain (Channel Islands, Isle of Man, Gibraltar), Italy (Campione d'Italia, Livigno), Portugal (Azores, Madeira) and Spain (Canary Islands, Ceuta, Melilla). Mount Athos is also a special territory but its civil governor is appointed by the Greek minister of foreign affairs. Overseas countries and territories are disregarded because they are not part of the EU and their relationship is governed by association agreements.

15 This analysis of cross-level variation follows Steenbergen and Jones (2002: 224, 231). We opted for a binomial model with a probit link function because subnational involvement reflects an underlying interval variable. Hence, its cumulative distribution is normal.

16 A table listing the marginal effect of the decentralisation indices and its standard error for each member state is available from the authors.

17 The marginal effects and confidence intervals have been produced following the code developed by Brambor et al. (2006). We took 10,000 draws from the estimated coefficients and the variance-covariance matrix. In Figure 3, number of SNAs is set at 15, while in Figure 4 shared rule is set at 2.4.

18 Since legislative measure and subnational measure cannot be observed for directives without national implementing measures, these observations drop out from the analysis.

19 As post-estimation diagnostic tests, we have employed the link test and inspected the Cox-Snell residuals to assess the appropriateness of the Cox specification. Each covariate was also plotted against the martingale residuals to assess if their functional form was correct. Finally, we used the Schoenfeld residuals to test if the covariates violated the proportional hazards assumption and, following Box-Steffensmeier and Jones (2004: 131-7), we interacted the offending covariates with the natural logarithm of time. The results also hold if these covariates are interacted with time only, rather than with its natural logarithm.

\section{REFERENCES}

Bache, I. (2004) 'Multi-level governance and European Union regional policy', in I. Bache and M. Flinders (eds), Multi-Level Governance, New York: Oxford University Press, pp. 165-78.

Baliu, M.K. (2008) 'Better regulation for EU regions: a reflection on the impacts of EU regulations on the regions', Eipascope 2008(2): 27-31.

Berglund, S., Gange, I. and Van Waarden, F. (2006) 'Mass production of law. Routinization in the transposition of European directives: a sociological institutionalist account', Journal of European Public Policy 13(5): 692-716.

Bindi, F. and Cisci, M. (2005) 'Italy and Spain: a tale of contrasting effectiveness in the EU', in S. Bulmer and C. Lequesne (eds), The Member States of the European Union, Oxford: Oxford University Press, pp. 142-63. 
Bomberg, E. and Peterson, J. (1998) 'European Union decision making: the role of sub-national authorities', Political Studies 46(2): 219-35.

Borghetto, E., Franchino, F. and Giannetti, D. (2006) 'Complying with the transposition deadlines of EU directives: evidence from Italy', Rivista Italiana di Politiche Pubbliche 5(1): 7-38.

Börzel, T. (1998) 'Shifting or sharing the burden? The implementation of EU environmental policy in Spain and Germany', European Planning Studies 6(5): 537-53.

Börzel, T. (2002) States and Regions in the European Union. Institutional Adaptation in Germany and Spain, Cambridge: Cambridge University Press.

Börzel, T.A. and Risse, T. (2003) 'Conceptualising the domestic impact of Europe', in K. Featherstone and C. Radaelli (eds), The Politics of Europeanization, Oxford: Oxford University Press, pp. 57-80.

Box-Steffensmeier, J.M. and Jones, B.S. (2004) Event History Modeling: A Guide for Social Scientists, Cambridge: Cambridge University Press.

Brambor, T., Clark, W.R. and Golder, M. (2006) 'Understanding interaction models: improving empirical analyses', Political Analysis 14(1): 63-82.

Brown, A. (1999) 'Filtering EU environmental policies through the government layers: the Eia directive in Scotland and Bavaria', Environmental Politics 8(4): 66-89.

Bursens, P. (2002) 'Why Denmark and Belgium have different implementation records: on transposition laggards and leaders in the EU', Scandinavian Political Studies 25(2): 173-95.

Commission of the EC (2001) 'European governance: a white paper', Commission of the European Communities.

Commission of the EC (2007) 'A Europe of results: applying community law', Commission of the European Communities.

Committee of the Regions (2005) Procedures for Local and Regional Authority Participation in European Policy Making in the Member States, Luxembourg: Office for Official Publications of the European Communities.

Dimitrakopoulos, D.G. and Richardson, J. (2001) 'Implementing EU Public Policy', in J. Richardson (ed.), European Union: Power and Policy-Making, London: Routledge, pp. 335-56.

European and External Relations Committee (2008) 'Report on an inquiry into the transposition of EU directives', Edinburgh: The Scottish Parliament.

Giuliani, M. (2003) 'Europeanization in comparative perspective: institutional fit and national adaptation', in K. Featherstone and C. Radaelli (eds), The Politics of Europeanization, Oxford: Oxford University Press, pp. 134-55.

Hardacre, A. (2008) 'Better regulation - what is at stake?' Eipascope 2008(2): 5-10.

Haverland, M. (2000) 'National adaptation to European integration: the importance of institutional veto points', Journal of Public Policy 20(1): 83-103.

Haverland, M. and Romeijn, M. (2007) 'Do member states make European policies work? Analysing the EU transposition deficit', Public Administration 85(3): 757-78.

Héritier, A., Kerwer, D., Knill, C., Lehmkuhl, D., Teutsch, M. and Douillet, A.-C. (eds) (2001) Differential Europe: New Opportunities and Restrictions for MemberState Policies, Lanham, MD: Rowman \& Littlefield.

Hooghe, L. (1995) 'Subnational mobilisation in the European Union', in J. Hayward (ed.), The Crisis of Representation in Europe, London: Frank Cass, pp. 175-98.

Hooghe, L. (ed.) (1996) Cohesion Policy and European Integration: Building Multi-Level Governance, Oxford: Claredon Press.

Hooghe, L., Marks, G. and Schakel, A.H. (2008) 'Operationalizing regional authority: a coding scheme for 42 countries, 1950-2006', Regional \& Federal Studies 18(2): 123-42.

Hooghe, L., Schakel, A.H. and Marks, G. (2008) 'Appendix B: country and regional scores', Regional \& Federal Studies 18(2): 259-74. 
Jeffery, C. (2000) 'Sub-national mobilization and european integration: does it make any difference?' Journal of Common Market Studies 38(1): 1-23.

Jensen, C.B. (2007) 'Implementing Europe: a question of oversight', European Union Politics 8(4): 451-77.

Knill, C. and Lenschow, A. (1998) 'Coping with Europe: the impact of British and German administrations on the implementation of EU environmental policy', Journal of European Public Policy 5(4): 595-614.

König, T. and Luetgert, B. (2009) 'Troubles with transposition? Explaining trends in member-state notification and the delayed transposition of EU directives', British Journal of Political Science 39(1): 163-94.

Lampinen, R. and Uusikylä, P. (1998) 'Implementation deficit - why member states do not comply with EU directives', Scandinavian Political Studies 21(3): 231-51.

Lane, J.-E. and Ersson, S. (1999) Politics and Society in Western Europe, London: Sage.

Lijphart, A. (1999) Patterns of Democracy: Government Forms and Performance in ThirtySix Countries, New Haven, CT: Yale University Press.

Linos, K. (2007) 'How can international organizations shape national welfare states? Evidence from compliance with European Union directives', Comparative Political Studies 40(5): 547-70.

Mandelkern Group on Better Regulation (2001) Final Report, Brussels: Mandelkern Group on Better Regulation.

Marks, G., Hooghe, L. and Schakel, A.H. (2008) 'Measuring regional authority', Regional \& Federal Studies 18(2): 111-21.

Mastenbroek, E. (2003) 'Surviving the deadline: the transposition of EU directives in the Netherlands', European Union Politics 4(4): 371-95.

Mastenbroek, E. (2005) 'EU Compliance: still a "black hole"?' Journal of European Public Policy 12(6): 1103-20.

Mbaye, H.A.D. (2001) 'Why national states comply with supranational law: explaining implementation infringements in the European Union', European Union Politics 2(3): 259-81.

Persson, C. and Fandel, M.-H. (2007) 'Better regulation: a regional perspective', EPC Issue Paper, no. 53.

Rhodes, R.A.W. (1986) European Policy-Making, Implementation and Sub-Central Governments: A Survey, Maastricht: EIPA.

Siedentopf, H. and Ziller, J. (eds) (1988) Making European Policies Work: The Implementation of Community Legislation in the Member States, London: Sage.

Steenbergen, M.R. and Jones, B.S. (2002) 'Modeling multilevel data structures', American Journal of Political Science 46(1): 218-37.

Steunenberg, B. and Kaeding, M. (2009) "As time goes by": explaining the transposition of maritime directives', European Journal of Political Research 48(3): 432-54.

Tatham, M. (2008) 'Going solo: direct regional representation in the European Union', Regional \& Federal Studies 18(5): 493-515.

Thomson, R. (2007) 'Time to comply: national responses to six EU labour market directives revisited', West European Politics 30(5): 987-1008.

Thomson, R. (2009) 'Same effects in different worlds: the transposition of EU directives', Journal of European Public Policy 16(1): 1-18.

Tömmel, I. (1998) 'Transformation of governance: the European Commission's strategy for creating a "Europe of the regions", Regional \& Federal Studies 8(2): 52-80.

Treib, O. (2008) 'Implementing and complying with EU governance outputs', Living Reviews on European Governance 3(5), available at http://www.livingreviews.org/ 1reg-2008-5

Weyand, S. (1997) 'Inter-regional associations and the European integration process', in C. Jeffery (ed.), The Regional Dimension of the European Union. Towards a Third Level in Europe, London: Frank Cass, pp. 166-82. 